\title{
ERRATUM
}

\section{The benefit and risk of stereotactic radiosurgery for prolactinomas: an international multicenter cohort study}

TO THE READERSHIP: An error appeared in the article by Hung et al. (Hung Y-C, Lee C-C, Yang H-C, et al. The benefit and risk of stereotactic radiosurgery for prolactinomas: an international multicenter cohort study [published online August 2, 2019]. J Neurosurg. doi:10.3171/2019.4.JNS183443).

The affiliations for several authors were incorrect. These authors are listed below, followed by their corrected affiliations. The numbering used reflects that used for the affiliations in the now updated article.

Khaled Abdel Karim, MD, PhD, , ${ }^{6,17}$ Reem M. Emad Eldin, MD, PhD, ${ }^{6,18}$ Amr M. N. El-Shehaby, MD, PhD, ${ }^{6,16}$ Wael A. Reda, MD, PhD, ${ }^{6,16}$ Sameh R. Tawadros, MD, PhD 6,16

${ }^{6}$ Gamma Knife Center Cairo, Nasser Institute Hospital, Cairo; Departments of ${ }^{16}$ Neurosurgery and ${ }^{17}$ Clinical Oncology, Ain Shams University, Cairo; and ${ }^{18}$ Department of Radiation Oncology, National Cancer Institute, Cairo University, Cairo, Egypt

The article has been corrected online as of February 21, 2020.

Jason P. Sheehan, MD, PhD

Department of Neurological Surgery, University of Virginia, Charlottesville, VA

CORRESPONDING ARTICLE See pp 717-726.

INCLUDE WHEN CITING

Published online February 21, 2020; DOI: 10.3171/2020.12.JNS183443a.

CAANS 2020, except where prohibited by US copyright law 